\title{
Promoting Feliz Guest House Surabaya by Emphasizing Its Unique Selling Points in Its Marketing Booklet
}

\author{
Sanjaya, G. \\ English Department, Faculty of Languages and Literature, Petra Christian University, Siwalankerto 121-131, \\ Surabaya 60236, East Java, INDONESIA \\ E-mails: elysiasanjaya99@gmail.com
}

\begin{abstract}
Feliz Guest House is a 2-star hotel which located at J1. Raya Kendangsari No. 80, Surabaya. FGH is a guesthouse with a concept of a mini hotel. Their main competitors are Home Guest House, SepuluhEnam Homestay, and Savira Guest House. The main problem that FGH is facing is the decline of occupancy rate in the past three years. To solve the problem, I think FGH needs a marketing booklet that can help them promote and emphasize its unique selling points. A marketing booklet will be a good solution to the problem is because FGH can effectively promote the business to potential customers. By knowing the purpose of the company and its uniqueness, it will create a positive image on the customers' mind. The benefit that the company will get is that they can use it to promote their company and its products to the new customers in order to increase the sales.
\end{abstract}

Keywords: Promotion, Promotional Tool, Unique Selling Points, Marketing Booklet.

\section{INTRODUCTION}

Feliz Guest House was established by Mrs. Nanik Lilin on 8 August 2011. FGH has another branch in Banyuwangi. FGH Surabaya is located at Jln. Raya Kendangsari No. 80. The problem that Feliz Guest House is facing is the decline of their occupancy in the past three years. The decline of the occupancy rate occurred within 2015-2018. After doing the survey, most of the customers said that only few people know FGH and its concept. Many people think that FGH is just like the other guesthouses, but actually FGH offers a concept of a mini hotel, so that is why the price of FGH is more expensive compared to its competitors. In addition, most of them know FGH not from the promotion, but it is only from the word of mouth. This could be an indicator that FGH has bad promotional strategy. The cause of this problem is also because the salesperson did not have the right promotional tool to promote FGH and its unique selling points to their prospect.

After knowing the problem, I tried to offer them a marketing booklet in order to help them to promote their guesthouse and its products in an effective way to gain more customers in order to increase the sales.

Business Communication Project will give several benefits for Feliz Guest House Surabaya. First of all, by having the marketing booklet, it would help FGH to promote their products and its unique selling points to their potential customers in an effective way. The second, by having effective promotional tool, the customers would have a better understanding about what differentiate FGH from the other guesthouses so that the customer would have an interest to buy the products. Lastly, for all this time, they do not have a right promotional tool to emphasize FGH's unique selling points. This project would give them a booklet that they could use while doing the sales visit.

\section{PRINCIPLES USED FOR DESIGNING NEW PRODUCTS}

To finish this project, I use some information from books and online sources to understand about the definition, purposes, and features used in making a marketing booklet. Based on the book titled "an Introduction to Branding” (2005, p. 30), Melissa David, stated that Brand and Branding are: Brand is the name of the product or service that comes from a specific source. From the definitions I have got, I can conclude that Brand and Branding are two different things. Brand is a "trademark" of the products while branding is what we do to improve the brand. The American Marketing Association (AMA), the organization that represents marketing professionals in the United States and Canada, defined marketing as "the process of planning and executing the 
conception, pricing, promotion, and distribution of ideas, goods, and services to create exchanges that satisfy individual and organizational objectives" (Belch, 2012). En.oxforddictionaries.com defines the word "booklet" as a small, thin book with paper covers, typically giving information on a particular subject. From the definitions I have found above, I can conclude that Marketing Booklet is a book made by a company to promote their products to the potential customers.

Booklet media is an option that plays a role in a marketing strategy, especially for offline companies. Therefore, a booklet is important. According to a book "Why Your Business Needs a Printed Booklet Brochure or a Printed Catalog" (2014), Mark Hale, stated that there are several reasons why a company needs a booklet. First of all, a booklet printing establishes expertise and trust so when the customers see a nice printed booklet it will indirectly represent an investment and communicates that the company is an established and reputable company. Second, booklet connects with customers. Third, booklet adds value and motivates more sales. So, having a marketing booklet is also one of the ways we promote or sell our products and services. When we give a well-designed booklet in the hands of the prospect customers, we will give more product knowledge to them and we will sell more.

There are several important elements that should be included in a marketing booklet. I use two sources as my guide in determining the contents of my final project. First, according to an online article "Tips for Better Sales Booklet", by Tara Hornor (2012), a booklet contains five basic elements. The elements are the table of contents, the company overview, the products, the how-to guides or benefits, and the contact information. The second, according to another online article "How to Create a Marketing Booklet", Kdavidson, stated that a marketing booklet consists of four things; case studies, products/services, FAQ (Frequently Asked Questions), and contact information of the company.

\section{PRODUCTS AND RATIONALE}

A marketing booklet is the important tool for FGH to have in order to promote and emphasizing its Unique Selling Points to customers clearly. The messages in a booklet aiming to give customers better understanding about FGH and its products.

In the marketing booklet that I made, there are four important components. I applied the theory of Tips for Better Sales Booklet and How to Create a Marketing Booklet. The first part is about company overview. This part contains the general information in two paragraphs about Feliz Guest House Surabaya such as the establishment year, the owner, the concept, the location, facilities, and services. In addition, I also put the Unique Selling Points in the paragraph that is Good Facilities, Affordable, and Strategic Location. The second important component is the products description. This part contains the types of rooms that FGH has; Standard Queen Room, Standard Twin Room, Junior Suite Room, and Suite Room. Additional information in the product description is the in-room facilities. In this part I also mentioned one of the FGH's USP that is facilities. The third important component is the Customers' Review. In this part, I took the online customers' review from Traveloka to support the USP that FGH has. It included the rate and the testimonials. The fifth important component is the Contact Information. This part contains address, telephone number, Email, website, and Instagram account of FGH. The language of the contents is written in English.

The main target market of this marketing booklet is the business people because they have a big contribution for Feliz Guest House. Another target market is the companies or organisation, individual, and travel agencies. By having or seeing the booklet, those who did not know about Feliz Guest House will aware of its uniqueness. The readers also will get better understanding about the products. In addition, by giving the booklet to travel agencies, in hope will help Feliz Guest House to promote and emphasize the USP to the potential customers.

The marketing booklet will be very useful for Feliz Guest House. The advantage of the booklet is the effectiveness. By having the booklet means FGH has an effective promotional tool. The booklet has quite spacious space to contain important information and to emphasize the Unique Selling Points of FGH. Therefore, marketing booklet is the best promotional tool rather than brochure and flyer.

For the Business Communication Final Project, I decided to make a marketing booklet for Feliz Guest House Surabaya with the title "Promoting Feliz Guest House Surabaya by Emphasizing its Unique Selling Points in its Marketing Booklet". The reason why I made the booklet is because the 
contents of the booklet attract the customers and will give them better understanding about Feliz Guest House and its uniqueness. Compared to brochure and flyer, booklet could contain more complete information and it is more effective in solving the problem that Feliz Guest House has.

By having the booklet, FGH use the space in it to put important information and its uniqueness since the booklet consists of 8-12 pages. Also, the target market of a booklet is companies. Companies represent business people, that being said, the target of the booklet matches with the target market of FGH. Therefore, considering about the function and the target market, I think a marketing booklet is the right tool for Feliz Guest House.

Firstly, the design of the marketing booklet is minimalist and contemporary. I chose the design because I wanted to make the booklet looks simple but modern. Next, based on the procedures to make a Marketing Booklet by Mark Hale (2014), he stated that "try to use the same colours, fonts, and tone for the lay-out design to make the prospects think that the company is consistent." the basic color that I used in the whole booklet is white and kind of gold color. I used the same color and font in order to keep the consistency of the lay-out design.

Secondly, I chose four important components for the content of the booklet based on the theories by Tara Honor and KDavidson. From the theories that I got, I will only use some of the elements such as Contact Information, About Feliz Guest House, Products Description, and Customers' Review. I considered these things as the main information needed by the potential customers. People tend to look at the general information about FGH, the type of the products / rooms, and the reviews about the company itself. Therefore, those components are really important to be included in the booklet. The reason why the booklet is in English was because I wanted the booklet look professional. In addition, even though their main target market is business people, but sometimes there are also overseas backpackers who purchase the product of FGH.

Thirdly is about the order of the components in the booklet. The total page number of the booklet is 12 . On the first page which is the front cover contains the pictures of the company's building and the contact information. The second page contains the logo of Feliz Guest House and its tagline "Comfortable Place, Affordable Price". The third page contains the general information about Feliz Guest House. The fourth and fifth page contains the products description. The sixth page contains the other facilities and services that Feliz Guest House offers. The seventh page contains the nearby important place information. The ninth and tenth page contains the customers' review on Traveloka. The eleventh page contains the map. The twelfth page, which is the back cover, contains the logo of Feliz Guest House, Petra Christian University, and English of Business Communication. In accordance with the agreement between the owner and me, I put my name as a credit at the back of the cover. The order of the components based on the order of importance from the most important into the not-so important. The reason why I decided to set the contents in that order is because business people mostly busy and they do not want to waste a lot of their time to read. As a result, people tend to read the most important parts only.

For pictures, I applied the theory of "How to Create a Marketing Booklet" (2014), by Mark Hale, which stated "to make the marketing booklet look more attractive, the writer has to put some relevant pictures of the business. However, the writer cannot just put all of the pictures that s/he has. The writer needs to choose the high quality pictures because it can positively influence the prospects that are looking at her/his booklet". I used the high quality pictures for the products and the other pictures which represent the important information. It also means I cannot just put the pictures which are not relevant. Therefore, I am going to link the pictures of the booklet and the theory I used.

\section{CONCLUSION}

The idea of making the marketing booklet came up because Feliz Guest House is facing a serious problem. The problem is the decline of the occupancy rate in the past three years, from 2015 - 2018. The cause of the problem was because they could not promote and emphasize their unique selling points in an effective way. As a result, only few people know Feliz Guest House and its uniqueness. This is a serious problem and should be solved. Finally, I give them the idea to make a new promotional tool to help them promote the guesthouse to the new potential customers. The new promotional tool that Feliz Guest House needs is a marketing booklet which I think and sure it could be the right solution to solve the problem that they have. A marketing booklet will be very helpful 
for them because it can promote Feliz Guest House and emphasize its unique selling points since the booklet contains complete information needed by the customers.

There are four main components in the marketing booklet that I made. The main components are the Company Overview, Products Description, Customers' Reviews or Feedbacks, and the Contact Information. I used some concepts in deciding the elements of the booklet from the online articles. Those concepts helped me a lot in making the contents or components of the booklet.

At the end, I really hope that the marketing booklet can be used effectively by Feliz Guest House Surabaya in order to increase the occupancy or the sales of the guesthouse. Feliz Guest House can distribute the booklet to the companies, organization, individual, travel agencies, and social media to promote their products and uniqueness.

\section{REFFERENCES}

Antaresa. (2018). 7 Tips Membangun Company Branding. Retreieved from https://blog.sribu.com/tips-membangun-company-branding/

Belch, G. E., and Belch M. A. (2012). Advertising and Promotion. New York: McGraw-Hill Companies, Inc

David, M. (2005). An Introduction to Branding. Switzerland: AVA Publishing SA

Davidson, K. (2017). How to Create a Marketing Booklet. Retrieved from http://ehow.com/how_2172922_marketing-booklet.html

Hale, M. (2014). Why Your Business Needs a Printed Booklet Brochure or a Printed Catalog. Retrieved from https://wilsonprintingusa.com/learn-marketing/business-needs-printedbooklet-brochure-printed-catalog-2/

Hornor, T. (2012). Tips for Better Sales Booklets. Retrieved from https://www.business2community.com/marketing/tips-for-better-sales-booklets-0274390 